\title{
UJI CEMARAN BAKTERI DAN CENDAWAN PADA KEJU KASAR (Cheddar)
}

\author{
Srikandi \\ Fakultas MIPA, UNB Bogor \\ Jl. K. H. Soleh Iskandar Km. 4, Cimanggu, Tanah Sareal - Bogor 16166 \\ Telp. 0252-8340217, 7535605 \\ sriuus@yahoo.co.id
}

\begin{abstract}
Contamination Test of Bacteria and Fungi on Rough Cheese (Cheddar)
\end{abstract}

\begin{abstract}
Foodstuffs such as cheese as a source of nutrition for humans, is also a food source for microorganisms. The growth of microorganisms in foodstuffs can cause adverse or beneficial change. Quality cheese can be seen from the presence of bacteria and mildew stains on the cheese samples. This study aimed to determine quantitatively the presence of bacteria and fungi in ten samples of coarse cheese (Cheddar) from five traditional markets in Bogor. Testing performed at the microbiology laboratory a contamination of bacteria of Salmonella sp and Listeria monocytogenes and yeast. The research results from ten samples of coarse cheese (Cheddar) had stain of pathogenic bacteria of Listeria monocytogenes and Salmonella sp Based on standar method of SNI 19-2897 - 1992 was negative/25g of sampel or mold and yeast was <10 cfu / g. Sample Zt was concluded that no contamination and Save to be consumend.
\end{abstract}

Key words : Cheese (Cheddar), Bacteri and Fungi

\begin{abstract}
ABSTRAK
Bahan makanan seperti keju selain merupakan sumber gizi bagi manusia, juga merupakan sumber makanan bagi mikroorganisme. Pertumbuhan mikroorganisme dalam bahan pangan dapat menyebabkan perubahan yang merugikan atau menguntungkan. Kualitas keju dapat dilihat dari keberadaan cemaran bakteri dan cendawan, pada sampel keju. Penelitian ini bertujuan untuk mengetahui secara kuantitatif keberadaan bakteri dan cendawan pada sepuluh sampel keju kasar (Cheddar) dari lima pasar tradisional di Bogor. Pengujian dilakukan di laboratorium mikrobiologi berupa uji cemaran bakteri Salmonella sp, Listeria monocytogenes dan cendawan. Data hasil penelitian dari sepuluh sampel keju kasar (Cheddar) diantaranya untuk cemaran bakteri patogen Salmonella sp dan Listeria monocytogenes berdasarkan metode SNI 19-2897-1992 hasilnya yaitu negatif/25g serta kapang dan khamir hasilnya $<10 \mathrm{cfu} / \mathrm{g}$ sehingga nilai cemaran mikroba dikatan memenuhi standar dan layak untuk dikonsumsi.
\end{abstract}

Kata kunci : Keju (Cheddar), Bakteri dan Cendawan

\section{PENDAHULUAN}

Bahan makanan seperti keju selain merupakan sumber gizi bagi manusia, juga merupakan sumber makanan bagi mikroorganisme. Pertumbuhan mikroorganisme dalam bahan pangan dapat menyebabkan perubahan yang merugikan atau menguntungkan, perubahan yang menguntungkan salah satunya adalah perbaikan bahan pangan secara gizi, daya cerna ataupun daya simpannya.
Beberapa makanan bisa dinyatakan aman untuk dikonsumsi, jika makanan tersebut diproses dengan proses dekontaminasi yang terkontrol dengan baik seperti pasteurisasi dan sterilisasi, contohnya susu, keju, es krim dan makanan-makanan kaleng. Bahan pangan tersebut dapat bertindak sebagai perantara atau substrat untuk pertumbuhan mikroorganisme patogenik dan organisme lain penyebab penyakit. Penyakit menular yang cukup berbahaya seperti tifus, kolera, dan disentri mudah tersebar melalui bahan 
makanan. Bakteri enteropatogenik penyebab infeksi dan intoksisasi, diantaranya Salmonella sp, Clostridium perfringens, Escherichia coli, Yersinia entercolitica dan Listeria monocytogenes (Winarno ${ }^{\mathrm{a}}$, 2007).

Keracunan makanan oleh Salmonella sp merupakan jenis infeksi yang diakibatkan karena mengkonsumsi makanan yang didalamnya terjadi proliferasi bakteri Salmonella sp. Bakteri ini bersifat Gram negatif dan fakultatif anaerob, berbentuk basil dengan flagella karena itu jenis bakteri tersebut mampu bergerak. Salmonella sp menyebabkan penyakit yang disebut salmonellosis yang ditandai dengan gejala seperti demam, sakit kepala, diare, kram perut, mual-mual, dan muntah yang biasa muncul dalam 6-72 jam setelah memakan makanan yang terkontaminasi Salmonella sp (Winarno ${ }^{\mathrm{b}}$, 2007).

Selain bakteri Salmonella sp yang dapat mengkontaminasi makanan ada bakteri lain yaitu Listeria monocytogenes dilaporkan sering mengkontaminasi keju, susu pasteurisasi, dan daging setengah matang. Suhu lingkungan optimal bakteri Listeria monocytogenes untuk mampu hidup dan berkembangbiak adalah $4^{0}-37^{\circ} \mathrm{C}$. Suhu $4^{0} \mathrm{C}$ umumnya terdapat pada lemari pendingin makanan. Apabila produk makanan atau minuman tercemar oleh Listeria monocytogenes kemudian makanan atau minuman tersebut di simpan dalam lemari pendingin, berarti memberikan suhu optimal untuk Listeria monocytogenes berkembangbiak. Oleh karena itu perlu dilakukan penelitian mengenai keju yang ada di pasar tradisional khususnya keju keras (Cheddar) apakah tercemar oleh bakteri patogen.

\section{BAHAN DAN METODE}

\section{Bahan}

Bahan yang digunakan sampel keju dari lima pasar tradisonal yang ada di Kota dan Kabupaten Bogor. Media Lactose Broth (LAB), Media Selenite Cysteine Broth (SCB), Media Tetrathionate Broth (TTB), Media Agar Xylose Lysine
Desoxycholate (XLD), Media Agar Hektoen Enteric Agar (HEA), Media Nutrient Agar (NA), Media Triple Sugar Iron Agar (TSIA), Urea Agar, Media Lysine Decarboxylase, Media Voges Proskauer (VP), Media Trypthone (Indol), Larutan $\alpha$-naftol, Pereaksi $\mathrm{KOH}$, Kristal keratin, Media Listeria Enrichment Broth (LEB), Media Listeria Selective Agar (LSA), Media Agar PALCAM, Media Agar Triptcase Soy Agar dengan 0.6\% Yeast Extract (TSAYE), $\mathrm{NaCl} 0.85 \%$, Minyak Imersi, Pewarna Kristal Violet, Larutan Lugol, Alkohol Absolut 96\%, Pewarna Safranin, Akuades Steril, $\mathrm{H}_{2} \mathrm{O}_{2}$ 3\%, dan Media Sheep Blood Agar, Media Potato Dextrose Agar (PDA), Chlorampenicol, Campuran Selen, $\mathrm{H}_{2} \mathrm{SO}_{4}$ pekat, Larutan $\mathrm{NaOH} 30 \%$, Indikator PP, Larutan $\mathrm{H}_{3} \mathrm{BO}_{3} 10 \%$, Larutan $\mathrm{HCl} 0.01 \mathrm{~N}$, Air Akuades, Larutan $\mathrm{HCl} 25 \%$, dan Heksane.

\section{Uji Bakteri Salmonella sp (SNI 19-2897- 1992 butir B.4)}

1) Pra pengkayaan

a) Sampel keju sebanyak 25 gram dimasukkan ke dalam wadah yang berisi $225 \mathrm{ml}$ LAB kemudian dihomogenkan.

b) Diinkubasikan ke dalam inkubator pada suhu $36 \pm 1{ }^{0} \mathrm{C}$ selama 16-24 jam.

2) Pengkayaan

a) Dipipet $10 \mathrm{ml}$ biakan prapengkayaan ke dalam $100 \mathrm{ml}$ TTB, dan diinkubasikan pada suhu $43{ }^{\circ} \mathrm{C}$ selama 24 jam.

b) Dipipet $10 \mathrm{ml}$ biakan prapengkayaan ke dalam $100 \mathrm{ml}$ SCB, dan diinkubasikan pada suhu $35-37{ }^{\circ} \mathrm{C}$ selama 24 jam.

3) Penanaman pada media selektif XLD dan HEA

4) Tes Penegasan (Uji Biokimia)

a) Triple Sugar Iron Agar (TSIA)

b) Urea agar

c) Lysine Decarboxylation Medium

d) Media Voges Proskauer (VP) 
e) Media Trypthone (Indol)

Uji Bakteri Listeria monocytogenes (187-1/MU/SMM-SIG)

1) Penyiapan dan homogenisasi contoh

a) Sampel keju sebanyak 25 gram dimasukkan ke dalam wadah yang berisi $225 \mathrm{ml}$ LEB, kemudian dihomogenkan.

b) Diinkubasikan ke dalam inkubator pada suhu $35-37{ }^{\circ} \mathrm{C}$ selama $24-48$ jam.

2) Penanaman pada media selektif

a) Setelah inkubasi, digores ke media LSA dan PALCAM. Dilakukan kontrol positif dan negatif.

b) Diinkubasikan ke dalam inkubator pada suhu $37{ }^{0} \mathrm{C}$ selama $24-48$ jam.

c) Diamati koloni L. monocytogenes pada kedua media dengan ciri yaitu koloni yang mempunyai zona (halo) berwarna hitam.

d) Dipilih 5 atau lebih koloni tunggal dan goreskan pada permukaan Media Agar TSAYE dalam cawan petri yang sudah disiapkan terlebih dahulu dan diinkubasikan pada suhu $30{ }^{\circ} \mathrm{C}$ selama $24-48$ jam.

e) Tes Penegasan (Uji Biokimia)
a) Uji Motilitas
b) Pewarnaan Gram
c) Uji Katalase
d) Uji hemolitik

\section{Uji Cendawan (Metode Plate Count (SNI} 19-2897-1992 butir B.9)

a. Lakukan persiapan dan homogenisasi contoh

b. Pipet $1 \mathrm{ml}$ dari masing-masing pengenceran ke dalam cawan petri secara simplo dan duplo

c. Ke dalam setiap cawan petri tuangkan sebanyak 12 - $15 \mathrm{ml}$ PDA yang telah dicairkan yang suhunya $45 \pm 1{ }^{0} \mathrm{C}$ dalam waktu 1 menit dari pengenceran pertama. Goyangkan cawan petri dengan hati-hati dan kerjakan pemeriksaan blanko.

d. Setelah membeku masukkan cawan petri dengan posisi terbalik ke dalam inkubator pada suhu $25 \pm 1{ }^{\circ} \mathrm{C}$ selama 3 - 5 hari.

e. Catat pertumbuhan koloni pada setiap cawan yang mengandung 25 - 250 koloni setelah 3 - 5 hari.

f. Hitung jumlah kapang dalam 1 gram atau $1 \mathrm{ml}$ contoh dengan mengalikan jumlah rata - rata koloni pada cawan dengan factor pengenceran yang digunakan.

\section{HASIL DAN PEMBAHASAN}

\section{Keju}

Produk keju yang digunakan sebagai bahan penelitian ini adalah keju olahan jenis keju keras tak bermerk dari pasar tradisional. Kemasan primer keju berupa lapis aluminium foil dengan beberapa lapis plastik. Keju olahan tersebut diambil dari 10 (sepuluh) pasar tradisional di daerah Bogor. Kondisi keju sebelum dianalisa secara visual memiliki penampakan yang baik, tidak berjamur, dan utuh. Kondisi penyimpanannya ditempatkan di suhu ruang dan refrigerator. Umur keju yang digunakan untuk penelitian sekitar 2-3 bulan. Dasar pemilihan keju ini adalah sering dikonsumsi baik oleh konsumen rumah tangga, pedagang ataupun para pemilik usaha makanan.

Keju olahan merupakan keju yang memiliki kandungan lemak yang rendah dan memiliki kadar air yang tinggi. Keju olahan merupakan keju yang didapat dari bahan baku keju yang sama tetapi dilelehkan pada usia dua sampai empat minggu dan telah ditambahkan air, antimycotic seperti asam sorbat, dan bahan tambahan makanan lainnya.

Salah satu keju olahan yang sangat populer dan banyak diproduksi yaitu keju cheddar. Keju cheddar merupakan jenis dari keju keras dengan perbandingan lemak dan kasein berkisar antara 1:0,68 1 : 0,72 (Dardanella, 2007). Keju cheddar kadang dimodifikasi dengan menggunakan 
pewarna makanan kedalamnya. Jenis pewarna makanan yang biasa digunakan dalam keju cheddar adalah anato yang didapat dari ekstrak tumbuhan achiote yang dapat memberikan warna kuning kemerahan (oranye) keju cheddar lebih dalam.

Keju cheddar yang baik menurut Dardanella (2007) adalah yang memiliki kadar air tidak lebih dari 39\%, dan kadar lemak kurang dari $50 \%$. Selain itu bahan baku segar telah mengalami proses pasteurisasi dan keju yang siap dikonsumsi minimal telah diperam selama 60 hari.

Keju cheddar olahan menurut SNI 01-2980-1992 adalah produk berupa padatan plastis yang diperoleh melalui pengolahan keju dengan penambahan pengemulsi dan pemanasan dengan atau penambahan bahan tambahan makanan lain yang diizinkan.

Tabel 1. Hasil Pengujian Bakteri pada Keju di Lima Pasar Tradisional

\begin{tabular}{|c|c|c|c|c|c|}
\hline \multirow{2}{*}{$\begin{array}{c}\text { PASAR } \\
\text { TRADISIO } \\
\text { NAL }\end{array}$} & \multirow[t]{2}{*}{ ULANGAN } & \multicolumn{2}{|c|}{ Salmonella sp. } & \multicolumn{2}{|c|}{ L. monocytogenes } \\
\hline & & Standar & Hasil & Standar & Hasil \\
\hline \multirow{3}{*}{ Pasar Bogor } & Keju 1 & Negatif/25 g & Negatif/25 g & Negatif/25 g & Negatif/25 g \\
\hline & Keju 2 & Negatif/25 g & Negatif/25 g & Negatif/25 g & Negatif/25 g \\
\hline & Keju 3 & Negatif/25 g & Negatif/25 g & Negatif/25 g & Negatif/25 g \\
\hline \multirow{3}{*}{ Pasar Anyar } & Keju 1 & Negatif/25 g & Negatif/25 g & Negatif/25 g & Negatif/25 g \\
\hline & Keju 2 & Negatif/25 g & Negatif/25 g & Negatif/25 g & Negatif/25 g \\
\hline & Keju 3 & Negatif/25 g & Negatif/25 g & Negatif/25 g & Negatif/25 g \\
\hline \multirow{3}{*}{ Pasar Gn. Batu } & Keju 1 & Negatif/25 g & Negatif/25 g & Negatif/25 g & Negatif/25 g \\
\hline & Keju 2 & Negatif/25 g & Negatif/25 g & Negatif/25 g & Negatif/25 g \\
\hline & Keju 3 & Negatif/25 g & Negatif/25 g & Negatif/25 g & Negatif/25 g \\
\hline \multirow{3}{*}{ Pasar Darmaga } & Keju 1 & Negatif/25 g & Negatif/25 g & Negatif/25 g & Negatif/25 g \\
\hline & Keju 2 & Negatif/25 g & Negatif/25 g & Negatif/25 g & Negatif/25 g \\
\hline & Keju 3 & Negatif/25 g & Negatif/25 g & Negatif/25 g & Negatif/25 g \\
\hline \multirow{3}{*}{ Pasar Ciampea } & Keju 1 & Negatif/25 g & Negatif/25 g & Negatif/25 g & Negatif/25 g \\
\hline & Keju 2 & Negatif/25 g & Negatif/25 g & Negatif/25 g & Negatif/25 g \\
\hline & Keju 3 & Negatif/25 g & Negatif/25 g & Negatif/25 g & Negatif/25 g \\
\hline- & Kontrol Positif & Positif & Positif & Positif & Positif \\
\hline
\end{tabular}




\section{Cemaran Bakteri}

Hasil pengujian Salmonella sp dan Listeria monocytogenes pada 10 (sepuluh) sampel keju dari 5 pasar tradisional dapat dilihat pada Tabel 1 . menunjukkan semua sampel keju negatif/25 g. Standar cemaran bakteri untuk Salmonella sp dan Listeria monocytogenes yaitu negatif $/ 25 \mathrm{~g}$.

Meskipun keju tersebut diperoleh dari pasar tradisional tetapi keju tersebut disampling dalam kondisi baik dari sumbernya (beberapa pasar tradisional) walaupun tanpa merk. Keberadaan bakteri Salmonella sp dan Listeria monocytogenes sangat kecil kemungkinan didapat pada sampel karena bakteri ini termasuk bakteri patogen yang sedikit sekali ditemukan pada bahan pangan.

Adanya Salmonella sp pada bahan pangan dapat disebabkan oleh beberapa faktor diantaranya dari bahan baku keju yaitu susu. Susu yang berasal dari hewan yang sakit dapat mengkontaminasi pangan olahannya, namun keju diolah dari susu yang telah di pasteurisasi sehingga dimungkinkan bakteri patogen akan mati.

Pada pengerjaan control positif Salmonella, akan terlihat dari uji serologis. Salmonella dibedakan berdasarkan antigen somatik (antigen $\mathrm{O}$ ) dan flagellar (antigen $\mathrm{H})$. Antigen $\mathrm{O}$ berhubungan dengan lipopolisakarida pada permukaan luar membran terluar sel. Antigen $\mathrm{O}$ ini stabil terhadap panas, resisten terhadap alkohol dan larutan asam. Antigen $\mathrm{H}$ berhubungan dengan flagella peritrikus. Antigen $\mathrm{H}$ ini tidak tahan terhadap panas (Yuliatin, 2008).

Selama penyimpanan parameter parameter mutu (kandungan kimia, mikrobiologis, dan organoleptik) akan berubah oleh adanya pengaruh lingkungan misalnya suhu, kelembaban, dan tekanan udara atau komposisi makanan bahan itu sendiri. Suhu penyimpanan produk bahan pangan akan mempengaruhi jenis bakteri yang mungkin berkembang dan mungkin menyebabkan kerusakan. Suhu rendah sering digunakan untuk memperlambat kecepatan bakteri (Dardanella, 2007).
Khusus untuk bakteri Listeria monocytogenes akan tumbuh makin subur pada suhu dingin. Oleh karena itu Listeria monocytogenes tidak menutup kemungkinan tumbuh pada bahan pangan yang disimpan di lemari pendingin (kulkas). Namun pada penelitian ini diperoleh negatif, hal ini karena sampel keju yang di ambil dari pasar masih dalam keadaan baik dan tertutup aluminium foil dan plastik.

Pendinginan dapat memperlambat kecepatan reaksi - reaksi metabolisme, karena itu penyimpanan bahan pangan pada suhu rendah dapat memperpanjang masa hidup dari jaringan - jaringan di dalam bahan pangan. Hal ini disebabkan bukan hanya karena keaktifan resporasi menurun, tetapi juga karena pertumbuhan mikroba penyebab kebusukan dan kerusakan dapat dihambat (Winarno, 1992).

Penggunaan suhu rendah dapat dilakukan untuk menghambat atau mencegah reaksi-reaksi kimia, reaksi enzimatis atau pertumbuhan mikroba. Semakin rendah suhu semakin lambat proses tersebut. Penggunaan suhu rendah antara lain penyimpanan sejuk (cellar storage), pendinginan, dan penyimpanan beku.

Penyimpanan sejuk biasanya dilakukan pada suhu sedikit dibawah suhu kamar dan tidak lebih rendah dari $15^{\circ} \mathrm{C}$. Pendinginan adalah penyimpanan bahan pangan diatas suhu pembekuan yaitu -2 sampai $+10^{\circ} \mathrm{C}$. Pendinginan yang biasa dilakukan sehari - hari dalam lemari es pada umumnya mencapai $5-8^{0} \mathrm{C}$. Walaupun suhu pendinginan dapat menghambat pertumbuhan atau aktivitas mikroba atau mungkin membunuh beberapa bakteri tetapi pendinginan maupun pembekuan tidak dapat digunakan untuk membunuh semua bakteri (Winarno, 1992).

Pendinginan dapat menghambat atau memperlambat pertumbuhan mikroba karena mikroorganisme mempunyai suhu maksimal dan minimal sebagai batas suhu untuk pertumbuhannya. Pengaruh suhu terhadap pertumbuhan mikroorganisme disebabkan suhu mempengaruhi aktivitas 
enzim yang mengkatalisasi reaksi - reaksi biokimia dalam sel mikroorganisme. Di bawah suhu optimum, keaktifan enzim dalam sel menurun dengan semakin rendahnya suhu, akibatnya pertumbuhan sel juga terhambat.

Pada suhu pembekuan, semua keaktifan metabolisme juga akan terhenti. Enzim terhenti juga karena semua sel kekurangan cairan di sekelilingnya yang digunakan untuk menyerap zat makanan dan mengeluarkan sisa metabolisme yang mengakibatkan pertumbuhan sel terhenti sama sekali (Fardiaz, 1992).

Pertumbuhan mikroba dipengaruhi oleh berbaga faktor lingkungan diantaranya adalah suhu, $\mathrm{pH}$, aktivitas air, adanya oksigen dan tersedianya zat makanan. Oleh karena itu, kecepatan pertumbuhan mikroba dapat diubah dengan mengubah faktor lingkungan tersebut. Semakin rendah suhu yang digunakan dalam penyimpanan maka semakin lambat pula reaksi kimia, aktivitas enzim dan pertumbuahn mikroba (Fardiaz, 1992).

Faktor yang mempengaruhi proses pendinginan bahan adalah suhu, kecepatan udara dalam ruang pendinginan, komposisi atmosfer serta ada tidaknya ultra violet. Dianjurkan untuk mempertahankan suhu pendingin di bawah $5.6{ }^{0} \mathrm{C}$ agar dapat mengganggu pertumbuhan mikroba psikrofilik dan mencegah pertumbuhan mikroba pathogen seperti Salmonella sp, Listeria monocytogenes, dan Staphylococcus aureus. Ruang pendinginan memerlukan kondisi kelembaban yang sesuai karena perubahan kelembaban yang besar dapat menyebabkan bahan menjadi lembab dan terjadi pertumbuhan jamur (Winarno 1992).

\section{Cendawan}

Hasil pengujian cendawan pada sepuluh sampel keju dari lima pasar tradisional dapat dilihat pada Tabel 2 . dimana hasil menunjukkan semua sampel keju $<10 \mathrm{cfu} / \mathrm{g}$. Standar cemaran bakteri untuk cendawan yaitu $<10 \mathrm{cfu} / \mathrm{g}$.

Potensi terbesar bagi mikroba untuk tumbuh terutama pada permukaan kemasan adalah kapang apabila permukaan-permukaan kemasan mempunyai kelembaban yang sangat tinggi (Winarno,2007). Pada prakteknya, bahan bahan kemasan yang tipis termasuk aluminium foil dan plastik mempunyai lubang - lubang kecil yang dapat dimasuki mikroba termasuk kapang, khamir, dan bakteri.

Pada umumnya, kebanyakan kapang membutuhkan aw (activity water) minimal yaitu untuk pertumbuhan lebih rendah dibandikan dengan khamir dan bakteri. Semua kapang bersifat aerobic, yaitu membutuhkan oksigen untuk pertumbuhannya. Kebanyakan kapang dapat tumbuh pada kisaran $\mathrm{pH}$ yang luas, yaitu $\mathrm{pH} 2-8.5$, tetapi biasanya pertumbuhan akan lebih baik pada kondisi asam atau $\mathrm{pH}$ rendah (Fardiaz, 1992).

Pada penelitian ini tidak didapatkan kapang dan khamir yang tumbuh. Hal ini dimungkinkan karena ada beberapa faktor pengaman yang menahan masuknya mikroba melalui lubang kecil tersebut, yaitu antara lain :

1. Adanya efek tegangan permukaan, sehingga mikroba tidak dapat masuk melalui lubang-lubang kecil, kecuali bila mikroba disuspensikan dalam larutan yang mengandung bahan pembasah (wetting agents) dan tekanan di luar kemasan lebih besar dari tekanan di dalam kemasan.

2. Bahan kemasan yang umumnya digunakan mempunyai ketebalan sedemikian rupa sehingga lubang lubangnya sangat jarang dan sangat kecil.

Pada umumnya, kebanyakan kapang membutuhkan aw (activity water) minimal yaitu untuk pertumbuhan lebih rendah dibandingkan dengan khamir dan bakteri. Semua kapang bersifat aerobik, yaitu membutuhkan oksigen untuk pertumbuhannya. Kebanyakan kapang dapat tumbuh pada kisaran $\mathrm{pH}$ yang luas, yaitu $\mathrm{pH} 2-8.5$, tetapi biasanya pertumbuhan akan lebih baik pada kondisi asam atau $\mathrm{pH}$ rendah (Fardiaz, 1992). 
Beberapa kapang mengeluarkan komponen yang dapat menghambat organisme lain. Komponen ini disebut antibiotik, misalnya penisilin yang diproduksi oleh Penicillium chrysogenum, dan clavasin yang diproduksi oleh Aspergillus clavatus. Sebaliknya, beberapa komponen lain bersifat mikostatik atau fungistatik yaitu menghambat pertumbuhan kapang, misalnya asam sorbat, propionat, dan asetat, atau bersifat fungisidal yaitu membunuh kapang (Fardiaz, 1992).

Pada penampakannya keju memiliki warna kuning cerah dan mengkilat di sepanjang permukaannya. Hal ini disebabkan oleh penambahan minyak nabati pada saat proses produksi yang bertujuan untuk mencegah terjadinya evaporasi dan melindungi keju dari gangguan mikroorganisme yang merugikan. Selain itu, terdapat pengawet seperti asam sorbat yang digunakan untuk mencegah tumbuhnya kapang dan nisin yang digunakan sebagai antibiotik. Bahan pengawet pangan adalah zat aditif bahan pangan yang berupa substansi bukan gizi yang ditambahkan ke dalam bahan pangan dengan sengaja dalam jumlah yang kecil. Tujuan utama penambahan bahan pengawet adalah untuk menghambat pertumbuhan dan aktifitas mikroorganisme, baik bakteri, kapang dan khamir sehingga dapat memperbaiki penampakan, tekstur dan daya simpannya.

Tabel 2. Hasil Pengujian Cendawan pada Keju di Lima Pasar Tradisional

\begin{tabular}{|c|c|c|c|c|c|}
\hline \multirow{2}{*}{$\begin{array}{c}\text { PASAR } \\
\text { TRADISIONAL }\end{array}$} & \multirow[t]{2}{*}{ ULANGAN } & \multicolumn{2}{|c|}{ Kapang } & \multicolumn{2}{|c|}{ Khamir } \\
\hline & & Standar & Hasil & Standar & Hasil \\
\hline \multirow{3}{*}{ Pasar Bogor } & Keju 1 & $<10 \mathrm{cfu} / \mathrm{g}$ & $<10 \mathrm{cfu} / \mathrm{g}$ & $<10 \mathrm{cfu} / \mathrm{g}$ & $<10 \mathrm{cfu} / \mathrm{g}$ \\
\hline & Keju 2 & $<10 \mathrm{cfu} / \mathrm{g}$ & $<10 \mathrm{cfu} / \mathrm{g}$ & $<10 \mathrm{cfu} / \mathrm{g}$ & $<10 \mathrm{cfu} / \mathrm{g}$ \\
\hline & Keju 3 & $<10 \mathrm{cfu} / \mathrm{g}$ & $<10 \mathrm{cfu} / \mathrm{g}$ & $<10 \mathrm{cfu} / \mathrm{g}$ & $<10 \mathrm{cfu} / \mathrm{g}$ \\
\hline \multirow{3}{*}{ Pasar Anyar } & Keju 1 & $<10 \mathrm{cfu} / \mathrm{g}$ & $<10 \mathrm{cfu} / \mathrm{g}$ & $<10 \mathrm{cfu} / \mathrm{g}$ & $<10 \mathrm{cfu} / \mathrm{g}$ \\
\hline & Keju 2 & $<10 \mathrm{cfu} / \mathrm{g}$ & $<10 \mathrm{cfu} / \mathrm{g}$ & $<10 \mathrm{cfu} / \mathrm{g}$ & $<10 \mathrm{cfu} / \mathrm{g}$ \\
\hline & Keju 3 & $<10 \mathrm{cfu} / \mathrm{g}$ & $<10 \mathrm{cfu} / \mathrm{g}$ & $<10 \mathrm{cfu} / \mathrm{g}$ & $<10 \mathrm{cfu} / \mathrm{g}$ \\
\hline \multirow{3}{*}{ Pasar Gn. Batu } & Keju 1 & $<10 \mathrm{cfu} / \mathrm{g}$ & $<10 \mathrm{cfu} / \mathrm{g}$ & $<10 \mathrm{cfu} / \mathrm{g}$ & $<10 \mathrm{cfu} / \mathrm{g}$ \\
\hline & Keju 2 & $<10 \mathrm{cfu} / \mathrm{g}$ & $<10 \mathrm{cfu} / \mathrm{g}$ & $<10 \mathrm{cfu} / \mathrm{g}$ & $<10 \mathrm{cfu} / \mathrm{g}$ \\
\hline & Keju 3 & $<10 \mathrm{cfu} / \mathrm{g}$ & $<10 \mathrm{cfu} / \mathrm{g}$ & $<10 \mathrm{cfu} / \mathrm{g}$ & $<10 \mathrm{cfu} / \mathrm{g}$ \\
\hline \multirow{3}{*}{ Pasar Darmaga } & Keju 1 & $<10 \mathrm{cfu} / \mathrm{g}$ & $<10 \mathrm{cfu} / \mathrm{g}$ & $<10 \mathrm{cfu} / \mathrm{g}$ & $<10 \mathrm{cfu} / \mathrm{g}$ \\
\hline & Keju 2 & $<10 \mathrm{cfu} / \mathrm{g}$ & $<10 \mathrm{cfu} / \mathrm{g}$ & $<10 \mathrm{cfu} / \mathrm{g}$ & $<10 \mathrm{cfu} / \mathrm{g}$ \\
\hline & Keju 3 & $<10 \mathrm{cfu} / \mathrm{g}$ & $<10 \mathrm{cfu} / \mathrm{g}$ & $<10 \mathrm{cfu} / \mathrm{g}$ & $<10 \mathrm{cfu} / \mathrm{g}$ \\
\hline \multirow{3}{*}{ Pasar Ciampea } & Keju 1 & $<10 \mathrm{cfu} / \mathrm{g}$ & $<10 \mathrm{cfu} / \mathrm{g}$ & $<10 \mathrm{cfu} / \mathrm{g}$ & $<10 \mathrm{cfu} / \mathrm{g}$ \\
\hline & Keju 2 & $<10 \mathrm{cfu} / \mathrm{g}$ & $<10 \mathrm{cfu} / \mathrm{g}$ & $<10 \mathrm{cfu} / \mathrm{g}$ & $<10 \mathrm{cfu} / \mathrm{g}$ \\
\hline & Keju 3 & $<10 \mathrm{cfu} / \mathrm{g}$ & $<10 \mathrm{cfu} / \mathrm{g}$ & $<10 \mathrm{cfu} / \mathrm{g}$ & $<10 \mathrm{cfu} / \mathrm{g}$ \\
\hline- & Kontrol Positif & Positif & Positif & Positif & Positif \\
\hline
\end{tabular}


Kapang dapat tumbuh dengan kondisi kelembaban sampel maupun lingkungan yang tinggi. Jika dilihat dari nilai kadar air pada beberapa sampel keju diperoleh nilai sebagian besar lebih dari standar. Namun keberadaan kapang dan khamir diperoleh negatif, ini dimungkinkan karena pada proses pengolahan keju tersebut banyak ditambahkan bahan pengawet agar sampel bisa bertahan lama.

Selain kapang, khamir pun bisa tumbuh pada medium yang sama. Kebanyakan khamir tumbuh paling baik pada kondisi dengan persediaan air cukup. Tetapi karena khamir dapat tumbuh pada medium dengan konsentrasi solut (gula atau garam) lebih tinggi daripada bakteri, dapat disimpulkan bahwa khamir membutuhkan air untuk pertumbuhan lebih kecil dibandingkan kebanyakan bakteri. Batas aktivitas air terendah untuk khamir berkisar antara 0.88-0.94, misalnya untuk khamir bir adalah 0.94 , untuk khamir yang ditemukan pada susu kental adalah 0.90, sedangkan untuk khamir roti adalah 0.905 (Fardiaz, 1992).

Banyak khamir bersifat osmofilik, yaiut dapat tumbuh pada medium dengan aktivitas air relatif rendah, yaitu sampai 0.62-0.65 pada sirup, meskipun beberapa khamir osmofilik tidak dapat tumbuh pada aktivitas air sekitar 0.78 dalam larutan garam maupun sirup. Masing-masing khamir mempunyai batas aktivitas air minimal dan kisaran aktivitas air untuk

\section{SIMPULAN DAN SARAN}

\section{Simpulan}

Keberadaan cemaran bakteri dan fungi mempengaruhi kualitas, rasa, dan warna dari keju. Dari sepuluh sampel keju yang diperoleh dari pasar tradisional yang ada di Kota dan Kabupaten Bogor yang memiliki kualitas terbaik yaitu keju 2 dari Pasar Bogor. Namun demikian, sampel keju lainnya masih layak untuk dikonsumsi.

\section{Saran}

pertumbuhan berbeda-beda, yaitu dipengaruhi oleh berbagai faktor seperti kandungan nutrien substrat, $\mathrm{pH}$, suhu, tersedianya oksigen, ada tidaknya senyawa penghambat (Fardiaz, 1992).

Kisaran suhu untuk pertumbuhan kebanyakan khamir pada umumnya hampir sama dengan kapang, yaitu dengan suhu optimum $25-30^{\circ} \mathrm{C}$ dan suhu maksimum $35-47^{\circ} \mathrm{C}$. Kebanyakan khamir lebih menyukai tumbuh pada keadaan asam, yaitu pada $\mathrm{pH}$ 4-4.5, dan tidak dapat tumbuh dengan baik pada medium alkali, kecuali jika telah beradaptasi. Khamir tumbuh dengan baik pada kondisi aerobik, tetapi yang bersifat fermentatif dapat tumbuh secara anaerobik meskipun lambat (Fardiaz, 1992).

Kebanyakan spesies khamir pertumbuhannya membentuk film pada permukaan, dan sering merusak makananmakanan yang mengandung garam dan asam dalam jumlah tinggi. Spesies yang bersifat lipolitik, yaitu Candida lipolytica sering menyebabkan kerusakan mentega dan margarin (Fardiaz, 1992).

Hasil negatif pada penelitian ini salah satunya dapat disebabkan karena pada sampel keju ini diperoleh nilai kadar abu yang tinggi. Tingginya kadar abu disebabkan karena tingginya.

Garam - garam mineral pada keju tersebut sehingga $\mathrm{pH}$ pada keju tersebut menjadi alkali atau basa. Kondisi alkali ini salah satu penyebab tidak tumbuhnya khamir.

Perlu dilakukan uji kandungan proksimat untuk mengetahui nilai gizi dari keju

\section{DAFTAR PUSTAKA}

Bell, C., P. Neaves, \& A. William, 2005. Food Microbiology and Laboratory Practice. United Kingdom : Blackwell Science.

Bennet, R. W dan E. W. Robert, 1995. Serodiagnosis of Listeria monocytogenes. $8^{\text {th }}$ edition/1995. FDA Bacteriological Analytical Manual. 
Dardanella, D., 2007. Pengaruh Jenis Kemasan dan Kondisi Penyimpanan Terhadap Mutu Produk Keju Cheddar Selama Penyimpanan. Fakultas Teknologi Pertanian IPB : Bogor.

Fardiaz, S., 1992. Mikrobiologi Pangan. Institut Pertanian Bogor : Bogor

Gandjar, Indrawati, Wellyzar Sjamsuridzal, \& Ariyanti Oetari. 2006. Mikologi Dasar dan Terapan. Jakarta : Yayasan Obor Indonesia.

Hitchins, Anthony D., 1995. Listeria monocytogenes. $8^{\text {th }}$ edition/1995. FDA Bacteriological Analytical Manual.

Standar Nasional Indonesia (SNI)., 2009. Batas Maksimum Cemaran Mikroba dalam Pangan. SNI 7388: 2009. Badan Standardisasi Nasional (BSN).

Standar Nasional Indonesia (SNI)., 1992. Cara Uji Cemaran Mikroba dalam Makanan. SNI 19-2891-1992.
Badan Standardisasi Nasional (BSN).

Standar Nasional Indonesia (SNI)., 1992. Cara Uji Cemaran Mikroba dalam Makanan. SNI 19-2897-1992. Badan Standardisasi Nasional (BSN).

Standar Nasional Indonesia (SNI)., 1992. Keju cedar Olahan. SNI 19-29801992. Badan Standardisasi Nasional (BSN).

Winarno, FG., 1992. Kimia Pangan dan Gizi. Gramedia Pustaka Utama : Jakarta.

Winarno, $\mathrm{FG}^{\mathrm{a}}$. , 2007. Teknobiologi Pangan. Bogor : MBrio Press.

Winarno, F. $\mathrm{G}^{\mathrm{b}}$. 2007. Analisis Laboratorium (Gastroenteritis dan Keracunan Pangan). Bogor : MBrio Press, cetakan 1.

Yualiatin, Fitri., 2008. Kemampuan Bertahan Salmonella Selama Proses Pembekuan Es. Fakultas Teknologi Pertanian IPB : Bogor. 